\title{
An Analysis of Samuel Barber's Neo-Romantic Music Style
}

\author{
Min Wang ${ }^{1, *}$ \\ ${ }^{1}$ School of Music and Dance, Liaocheng University, Liaocheng, Shandong 252059, China \\ *Corresponding author. Email: wangmin83317@163.com
}

\begin{abstract}
Samuel Barber is a famous American composer, known as "one of the most influential composers of American music in the twentieth century". Most of his works is categorized to string products. The creation of his works has extremely romantic style. Samuel Barber's music blends traditional musical styles with modern pop elements. He does not blindly follow trends in his creation, but maintains his own creative style. He is a distinctive music creator. Because of his unique style of music works, he is widely loved by the masses, and he is called a unique existence in the field of music creation. This article is specifically aimed at Samuel Barber's neo-romantic style of music analysis.
\end{abstract}

Keywords: Samuel Barber, Neo-romanticism, Style analysis.

\section{INTRODUCTION}

Samuel Barber is a representative figure in the field of contemporary music. His creation romanticism, traditional chords in music work creation techniques, and the use of the structure, have greatly promoted the expression of music emotion and music uniqueness. With the increase of age and enriched the learning experience, Samuel Barber's music style gradually shift in music creation, reducing the application of traditional techniques, highlighting the melody and rhythm of music, improving the impression of the masses on romantic music, and enriching the emotional elements of music.[1][2]

\section{TRADITIONAL MUSIC EXPRESSION IN THE ROMANTIC MUSICISM STYLE OF SAMUEL BARBER}

In Samuel Barber's creation, he always adhered to a unique way of artistic creation, integrated 19thcentury romantic music elements in his music creation, combined with his own music creation experience, and gradually improved and changed the perspective of music creation. Especially the expression of emotion, he incorporated traditional structures and chord techniques. The unique creative style is in sharp contrast with the music of other romantic composers in the same period. In Barber's music creation, most of the traditional music expressions are reflected in the early music creation. Due to the changes experienced in the middle and later stages, the creation style has changed.

\subsection{Application of Traditional Chord Techniques}

Among Barber's many music creations, "String Adagio" is a representative work in romantic music creation. In this work, Barber used a long and progressive melodic line as the main theme, then repeated seven times. It is the traditional structure of a single trilogy. The rhythm is very harmonious and soothing, the cello, the violin and the viola are combined in the creation, and the performance is developed in the order of "violin-viola-cello" alternately, bringing the listeners peace and beauty, as if being in tender love, is very romantic. [3]

The techniques of chord in this piece have showed the traditional characteristics and the ways on how to applying chord is different.

For example, the music begins to develop from the subordinate seventh chord, and ends on the dominant chord. It does not follow the usual chord rules and resolves to the end of the main chord, 
leaving a long aftertaste and adding a unique sound to the song. Secondly, this piece used the 4/2 tempo. Its rhythm, speed, duration and stress is interval far away. The composer's use of the harmony, polyphony and phrasing technique not only makes the rhythm of music have the wordy hearing but also have the procrastination. Instead of increasing the cohesion of the music, the music in the gathering of energy at the same time, deeply touched listener's heart. [4]

The "First Symphony" composed by Barber is his main representative work, using traditional triads in his creation. At the end of the creation, Barber added the $\mathrm{b}$ minor harmony of the string group woodwind group. In the fusion of harmony and traditional string music, he created a majestic and magnificent color for the music. Barber also applied the seventh chord in his creation. Deepen the traditional creation structure, and enhance the emotion in the works in the application of traditional chords.

\subsection{The Use of Traditional Musical Structure}

Barber has always maintained a unique creative style in music creation, applying the traditional musical structure in the "Chaos" and "Travel Collection" created by Barber. And in the first composition of "Travel Collection", the traditional structure of Rondo form was applied, and the traditional structure of sonata and variation was applied in the third composition, which was rendered by the traditional musical structure. All those highlight Barber's uniquely romantic style.

In the middle of the 20th century, the sonata form and Fugue selected in Barber's works are the creative means of tonal thinking, which is the highest framework mode of main and polyphonic music in traditional music. It coincides with Barber's rigorous logical structure and humanized development thinking of the golden mean theme "tonal twelve tones". In the traditional structure mode, Barber's works are unique -- the presentation of flag characteristics mainly depends on his different $\mathrm{Fu}$ inspiration and exquisite creative technology, but the key is that he strives for the "golden mean" unity of humanization and objectivity, inherits the tradition and innovates the tradition at the same time. For example, in Barber's famous work commemorative sketch, the innovative repertoire based on traditional skills and the wandering Tango of hesitation Tango are taken as examples. It belongs to a complex trilogy structure. In the creation of Part B of the music, Barber adopts continuous changes and repetitions of phrases, and each repetition expands on the texture, leading to the climax of the work in section 83. In his works, every movement is closely related, giving full play to the cyclic characteristics of rising, inheritance, transformation, and combination. In his creation, Barber pays great attention to the treatment of the middle of the movement. The creative treatment of the middle of the theme of each movement is an extension, full development, or variation of the original theme. [5]

\section{MODERN MUSICAL ELEMENTS IN SAMUEL BARBER'S ROMANTIC MUSIC}

Modern music elements are included in Barber's mature compositions. It is embodied in incongruous chords, complex and diverse beats, and diverse rhythm patterns. In Barber's mature period of creation, more and more of the rhythm in the music are presented.

\subsection{Complex and Diverse Beats}

Due to the influence of World War II, Barber's music creation style has undergone great changes. In this stage of creation, various beats have been incorporated, while the conversion of multiple beats has been improved, and the expression of traditional music emotions has been reduced in the creation. The use of traditional music style breaks through the traditional artistic style in this kind of creation. By adding the rhythm conversion in the creation, it is enhancing the sense of the rhythm of music works and the impression of the audience on the work. For example, in the music work "Green Piano Lowland" created by Barber, the beats are frequently changed and the application of mixed beats is increased. Through the change of beats and frequent applications, it presents an extremely free and inconsistent creative structure. In the creation, the rhythm and lyrics are unified, which improves the rhythm of the work, highlights the unique creative style, and perfectly expresses the creative emotion. Complex and diverse creative styles are reflected in many mature works.

\subsection{The Application of Inconsistent Chords}

The application of inconsistent chords in Barber's music creation can be embodied in fifthdegree superimposed chords and additional chords. For example, in Barber's "Piano Sonata", the fourth 
chord was used in the creation of the first movement, which improved the rhythm of the overall work and enhanced the modern musical elements in the creation. In the creation of "St. Patrick's Sanctuary", the fourth and fifth are used as fixed tones to interpret them in an uninterrupted manner. The coordination of the fifteenth superimposed harmony enhances the empty inspiration in the music. Accompanied by mysterious sound effects, it expresses the noisy and noisy emotions of the work. This creative method presents strong modern creative characteristics.

\subsection{Application of Various Rhythm Patterns}

In Barber's mature period of creation, a variety of rhythmic patterns were used, which is obviously different from the previous creative style. His creative style is bolder and forms a very sharp contrast with the traditional and old-fashioned style. The main rhythm patterns in the creation of Barber's music include Buji Uji, Ragtime and Latin rhythms. For example, in the fourth movement of "Piano Sonata" composed by Barber, the Ragtime rhythm is applied, which presents a unique artistic style, giving people an inconsistent jazz music style in terms of hearing; When Barber was creating "The Traveling Collection", the thirteenth bar of which was applied with Latin rhythms. The agile rhythm filled the music with vitality and enhanced the emotional expression of the music; at the same time, Barber was still in the first section of the same piece of music. Buji Uji rhythm is applied to make the music work present the characteristics of jazz music.

\section{THE FORMATION OF SAMUEL BARBER'S NEO-ROMANTIC MUSIC STYLE}

\subsection{Family Environment}

Barber was born into a musical family. His mother was a pianist, perhaps due to genetics or environmental influences. When he was only 14 years old, Barber was able to accurately play the melody he heard on the piano. He was admitted to the famous Curtis School of Music with his superb piano playing skills. Barber's aunt is a well-known singer, and his uncle is not only a well-known contemporary composer, but also an enlightenment teacher in Barber's composition and creation techniques, and has greatly helped her music creation. In such a family education and learning environment, Barber mastered a wealth of music theory knowledge, which laid the foundation for his future creation. So when Barber was young, he was heavily influenced by his family's artistic influence and technical guidance. In summary, Barber's artistic creation is directly related to his family. It can be said that the family environment directly provides Barber with favourable creative techniques and inspirations, which in turn forms his unique romantic music style.

In Samuel Barber's music creation, his family environment had a great influence on Barber. At the age of 10, Barber wrote his first work in his life called "The Rose Tree". It can be seen that there is a unique contemporary romantic style, and the development of Barber's romantic style is directly related to the family.

\subsection{Creation Style Change}

Neo-Romantic music was opposed at the beginning of new music in the last century. Romantic music with exaggerated emotional expression has strong irrational factors. Its characteristics gave birth to the music developed rationally by "Neo ancient music" and deeply penetrated by "Expressionism" with irrationality. "Expressionism" music exposed to the abnormal psychology of human repression, distortion and secret mentality; "Neoclassicism" music, which deliberately pursues the perfection of artistic form and deliberately ignores content and emotion; Barber's music style is full of personal emotional expression. Barber's creative period can be divided into three stages:

- $\quad$ The early stage, 1929-1939

Barber has the early learning of vocal music, with mellow baritone timbre. During his early stage, Barber mainly used vocal composition and semitone techniques for his creation. The tonality of the work is to express the music with lyrical style, characteristics and forms of expression, by showing the natural inflow of singing and romance in the music.

- The second stage: the transition phase (1940-1947)

During this period, Barber was constantly seeking to get rid of traditional tones and musical styles of expression, and compromise in principle, the elements of modernism gradually began to be integrated into his works. There are many dissonances as decoration in the music, so the music becomes more dramatic. 
- The third stage: the mature stage (after 1947)

Among all his works, Barber's works during this period are the most distinctive and charming. Because Barber has already occupied a dominant position in neo-romanticism at this time, and his music also clearly highlights his personal creative strength, so the works of this period are the most individual and the most representative. The music maintains the same lyrical style as always, natural and not artificial. The melody is smooth and flexible, with a soft color and a poetic touch. At the same time, the choice of tonality, the structure of music, and the use of harmony are no longer conservative. Barber's music has begun to become liberalized and individualized, and his works have gradually formed an incongruous style.

\section{CONCLUSION}

The American composer and critic V. Thomson once commented on Barber's musical style. He believes that Barber's main problem is that he "has not resorted to violence to expel the ghosts of romanticism." However, in fact, instead of expelling the "ghosts" of romanticism, Barber has incorporated a more personal understanding of the musical background and cultural environment of the era, and further demonstrated through the expression of emotions. Therefore, Barber is known as a neo-romantic composer. From the point of view of the creative technique, Barber used to adopt, he is closer to classicism. He insisted on adopting the sonata form in some of his concertos, symphonies, and other instrumental works. He once said this: "When the lyrics are paired with music, I immerse myself in the lyrics and let the music flow from the lyrics. When I write an abstract piano sonata or a concerto, I write what I feel." Samuel Barber's romantic style formation is due to his family environment and his working experience. Barber's early works showed the traditional musical expressions without much experience. With the increase of age, his music creation style has also undergone significant changes, showing a modern neo-romantic music style. Music creation is not only an art form but also has a direct relationship with family and personal learning and practical experience.

\section{AUTHORS' CONTRIBUTIONS}

This paper is independently completed by Min Wang.

\section{ACKNOWLEDGMENTS}

This article is the conclusion of the school level project in Liaocheng University: the research on the cultural ecological construction of new romantic music in the contemporary context. The project number is (201962).

It is also the interim result of the school level key first-class course "History of Western Music" in Liaocheng University.

It is the result of the ideological and political demonstration course "History of Western Music" at Music and Dance School in Liaocheng University.

This article is a scientific research paper on the cultivation of young talents of "Xianlin Scholars" in Liaocheng City.

\section{REFERENCES}

[1] Tian Keyu, Zhang Ming. Exploration of Samuel Barber's Neo-Romantic Music Style [J]. Music World, 2018, (09): 53-57.

[2] Li Ke. Characteristics of Samuel Barber's Piano Music Composition [J]. Music Creation, 2018, (09):136-138.

[3] Chen Yiwen. A Probe into the Singing of Barber's Vocal Suite "Song of the Hermit"[D]. Wuhan Conservatory of Music, 2018.

[4] Gao Na. Research on Samuel Barber's NeoRomantic Music Style [D]. Hebei Normal University, 2017.

[5] Feng Wei, Zheng Si. The application of twelve-tone technique in Barber's piano solo works [J]. Art Education, 2016, (08): 110-111. 